Research Article

\title{
Preliminary Quantification of Phytochemicals in Methanolic Extract of Rosmarinus officinalis L. Using HPTLC
}

\author{
Pathania Singh Mamta ${ }^{1}$, Guleria Puspha ${ }^{1}$, Singh Hitender ${ }^{1}$, Bhardwaj Payal2 ${ }^{2}$, Pathania Singh Dhirendra ${ }^{3}$ \\ 1. Department of Botany, SILB, Solan Himachal Pradesh, India. \\ 2. Department of M.Tech in Material Science, University of Mysore, Karnataka, India. \\ 3. Department of Higher Education, HP, Shimla, India. \\ *Corresponding author's E-mail: payalpu_82@yahoo.co.in
}

Received: 02-07-2021; Revised: 24-08-2021; Accepted: 30-08-2021; Published on: 15-09-2021.

\section{ABSTRACT}

Rosmarinus officinalis L. commonly known as Rosemary belong to the family Lamiaceae. It is an aromatic herb which is hardy, dense and evergreen in natural habitat. It is one of the medicinal plants which is cultivated around the world for its medicinal, therapeutic purpose and is used as condiment and food preservative. It is one of the oldest Mediterranean shrub having strong, pungent aroma having dark green and elongated leaves with white or purple flowers. It is a perennial herb reaching 100 to $210 \mathrm{~cm}$ in height having pointed and hairy, resinous dark green leaves with lower white surface. The present study review about macroscopical/botanical description of Rosmarinus officinalis $\mathrm{L}$. and its methanolic extraction analysis for preliminary quantification of chemical constituents by visualizing TLC plate under different wavelength of UV light i.e., $255 \mathrm{~nm}, 366 \mathrm{~nm}$ and $566 \mathrm{~nm}$ to get chromatograph by HPTLC.

Keywords: Rosmarinus officinalis, Lamiaceae, HPTLC, Phytochemical constituents.

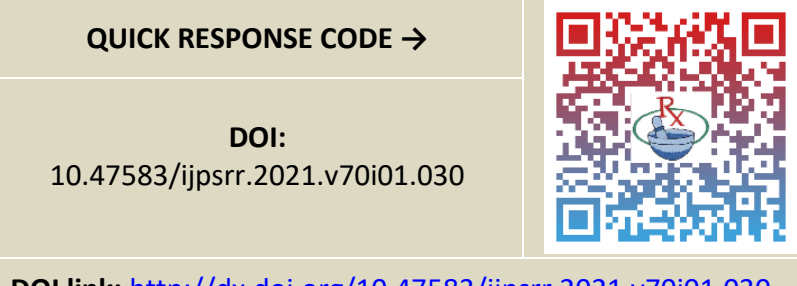

DOI link: http://dx.doi.org/10.47583/ijpsrr.2021.v70i01.030

\section{INTRODUCTION}

A

yurveda is believed to be prevalent since last 5000 years in India. It is one of the most noted system of medicine in the world ${ }^{1}$. Ayurveda is based on the fact that everything in the universe is composed of five main elements viz. Space, Air, Energy, Liquid and solid. The one of the important herb from ayurveda is Rosmarinus officinalis, commonly known as Rosemary. Rosemary is native to South Europe and Asia and is cultivated in Mediterranean basin and India. It is a perennial herb with fragrant, evergreen, needle like leaves. It is hardy in cool climates and can withstand drought. Forms of Rosemary range from upright (1.5 meter tall) to trailing. Leaves are 2$4 \mathrm{~cm}$ long and 2-5 $\mathrm{mm}$ broad and are dark green from the adaxial side and creamish white from the abaxial side having smooth edges that generally tends to curl slightly under the leaf base ${ }^{2}$. Plant flowers in spring and summer in temperate climates and can be constant bloom in warmer climate. Flowers are white, pink, purple or dark blue. Plant has tendency to flower outside its normal flowering. Seeds and cutting are common sources of regeneration of Rosmarinus officinalis ${ }^{3}$. This plant tolerates heat and drought hence grows in dry, rocky and sandy soils ${ }^{4}$. This modern medicine has gradually evolved over the years by scientific and observational efforts of scientists. Plant has played a crucial role in human health and improving the quality of human life for thousands of years and Rosmarinus officinalis is one of them which contains number of phytochemicals "Rosemarinic acid, camphor, caffeic acid, urosolic acid, Betulinic acid, carsonic acid and carsinol-which is used as an anticancerous compound in present day medicinal system ${ }^{5}$. Traditionally the oil of rosemary is used to treat muscle pain and arthritis and it is also used as incense and is also very in aroma therapy and many skin conditions ${ }^{6,7,8}$. Rosemary take its name from the Latin "Rosemaris" which means "dew of the sea". In the historical literature about Rosemary, it is found that the Rosemary was used as a cure for poor digestion, migraine, joint disorder and muscular aches $^{9}$. It is also used in the treatment of genitourinary conditions, liver diseases and scalp treatment ${ }^{10}$. The present study deals with the macroscopic and phytochemical analysis of Rosmarium officinalis, to highlight the potential use of this plant in therapeutic use.

\section{Morphological feature}

Rosemary is an aromatic evergreen shrub having leaves similar to home lock needles. Its forms ranges from upright to trailing. The upright forms can reach $1.5 \mathrm{~m}$ tall, rarely $2 \mathrm{~m}$.

\section{Root}

Short tap root system is present and lateral root form carpet which helps in anchorage and absorption.

\section{Stem}

The stem is divided into nodes and internodes. Leaves arise from the nodes. Stem perform the function of storage, asexual reproduction, protection or photosynthesis. 


\section{Leaves}

Leaves are simple and oppositely arranged along the stem leaf is stalked, crenate or serrated margin. The leaf blades are mostly egg shaped in outline with broad end at base(ovate) and have a strong aroma when crushed or rubbed.

\section{Flower}

The flowers of rosemary are white, pink, purple or blue colour and are bisexual.

Chemical constituents include Rosmarinic acid, Carnisol, Borneol, Camphor, Limolene, Camphene, Carsonic acid, Alpha terpinol, Cineole, Alpha Pinene and Caffeic acid ${ }^{11}$.

Rosemary is a rich source of antioxidants and antiinflammatory compounds, which are thought to help boost the immune system and improve blood circulation ${ }^{12}$. Laboratory studies have shown rosemary to be rich in antioxidants, which play an important role in neutralizing harmful particles called free radicals. Rosemary is often used to help treat indigestion ${ }^{13}$. Rosemary is used for the treatment of indigestion. The aroma from rosemary can improve a person's concentration, performance, speed, and accuracy and, to a lesser extent, their mood ${ }^{14}$ found that rosemary may also be good for your brain. Rosemary contains an ingredient called carnosic acid, which can fight off damage by free radicals in the brain. Some studies in rats have identified that rosemary might be useful for people who have experienced a stroke. Rosemary appears to be a protective agent against brain tissue damage and might improve the damaged portion. few studies have suggested that rosemary plays a significant role in preventing brain aging. The therapeutic ability of rosemary for prevention of Alzheimer's shows promise, but more studies are needed. Another study, published in Bioscience, Biotechnology and Biochemistry, concluded that rosemary might be useful as an anti-inflammatory and anti-tumor agent. Research published in Oncology Reports found that "crude ethanolic rosemary extract (RO)" slowed the spread of human leukemia and breast carcinoma cells ${ }^{15}$.

\section{MATERIALS AND METHODS}

\section{HPTLC Technique}

HPTLC is an advance type of thin layer chromatography (TLC) which conducts efficient separation with the help of favorable coating material. Where, chromatography is defined as physical process of effective separation of components in concentration-zone/phase different from those in which they are originally present, irrespective of the nature of the force or forces causing the substances to move from one phase to another ${ }^{16}$. With the HPTLC technique, various merits over traditional TLC, like this reduced the analysis time, reduce the amount of mobile face used, less amount of sample needed, enhance the data acquisitions and interpretation etc. The HPTLC differ from TLC in term of resolution of mixture (separation of two components of a mixture in a chromatogram). The resolution of mixture increased number of times as compared to TLC; therefore, it is termed as HPTLC works with principle of separation may result due to adsorption or partition or by both phenomena. Chemical analysts are preferring HPLC to identify and quantify the phytochemical for fast result ${ }^{17}$ but many of them using HPTLC and considered it as excellent for preliminary quantification before HPLC technique ${ }^{18}$.

\section{Plant material collection}

Samples (arial part of plants) for study were collected from Dr. Y.S. Parmar University of Horticulture and Forestry, Nauni, Solan (HP). The plant material was identified and confirmed with different macroscopic leaf characters (Colour, Odour, Shape, Petiole, Apex, Margin, Venation, size) in the Department of Botany SILB Institute, Solan. Different observed macroscopic characters of the leaves of Rosmarinus officinalis are given in Table 1.

The macroscopic characters of the leaves were observed as shown in Table 1.

Table 1: Macroscopical characters of Rosmarinus officinalis

\begin{tabular}{|c|c|c|}
\hline Sr. No. & Leaf Characters & Observation \\
\hline 1 & Colour & Blue-green1 \\
\hline 2 & Size & Lenth:2-4cm, Width 2-5mm \\
\hline 3 & Shape & Linear \\
\hline 4 & Leaf type & Simple \\
\hline 5 & Leaf texture & Waxy \\
\hline 6 & Odour & Pleasant \\
\hline 7 & Leaf Persistent & Evergreen \\
\hline 8 & Leaf Margin & Entire \\
\hline
\end{tabular}

\section{Preliminary photochemical analysis}

\section{Selection of chromatographic plate and its washing}

The TLC plate of dimension $10 \mathrm{~cm} \mathrm{X} 6 \mathrm{~cm}$ was selected having support material (Aluminum) and sorbent (Silica gel) over it. After selection pre-washing of plate with using Methanol: Water (9:1) was done to remove Iron impurities which are commonly found along with sorbent (Silica gel).

\section{Sample preparation}

For sample preparation $5 \mathrm{mg}$ of plant extract was dissolved in $20 \mathrm{ml}$ of methanol in a conical flask. Then flask was heated for 5 minutes at $20^{\circ} \mathrm{C}$ for proper mixing with covering its neck with aluminum foil. Then extract was filtered in beaker after proper dilution. Solvent system of TEF (5:4:1 Toluene: Ethyl acetate: Formic acid) was prepared separately in a jar. Simultaneously, a detector reagent; Anisaldehyde-Sulfuric reagent was prepared by dissolving $5 \mathrm{ml}$ Anisaldehyde, $10 \mathrm{ml}$ acetic acid, $80 \mathrm{ml}$ methanol and $5 \mathrm{ml}$ concentrated $\mathrm{H}_{2} \mathrm{SO}_{4}$ together in a separate beaker. 


\section{Application of sample}

Syringe was washed first using methanol and then sample of $20.2 \mu \mathrm{l}$ was taken with care to avoid bubbles in it otherwise it will affect the sample volume. TLC plate and syringe were placed in its position on sample injector. After pressing enter key on applicator, machine belt started to perform its work (samples were loaded automatically) and sample from syringe will be laid on TLC plate placed on applicator. Repeat the process again, as 2 replicates $\mathrm{R} 1$ and $\mathrm{R} 2$ are taken for spotting and profiling on same plate. Then TLC plate was displaced without touching on sample spots and was allowed for air drying.

\section{Mobile phase and detector reagent}

On the other side, Twin trough chamber was left earlier before 30 minutes for saturation which contained solvent mixture i.e., Toluene: Ethyl acetate: Formic acid (5:4:1) of $10 \mathrm{ml}$. Air dried TLC plate was marked at $8 \mathrm{~cm}$ from its bottom and was placed in the twin trough chamber. This chamber was placed stationary so that mobile phase moves up without any disturbance. Then detector chamber and detector reagent (Anisaldehyde Sulfuric reagent) were used to detect the constituents which are not visible with day-light. From the detector chamber TLC plate was placed in the oven at $105^{\circ} \mathrm{C}$ for 5 minutes to darken the spots on TLC plate.

\section{Scanning}

TLC scanner was used to visualize plate under UV at different wavelength i.e., $255 \mathrm{~nm}, 366 \mathrm{~nm}$ and $566 \mathrm{~nm}$. Size of plate (dimensions) and wavelength were set on the monitor screen. And finally, by spot recording or automatization peaks of different constituents were formed on the screen.

\section{RESULTS AND DISCUSSION}

\section{Microscopy}

\section{T.S of Rosmarinus officinalis leaf}

The transverse section of the leaf showed dorsi ventral nature. The leaf was divided into lamina and midrib region (Fig.1)

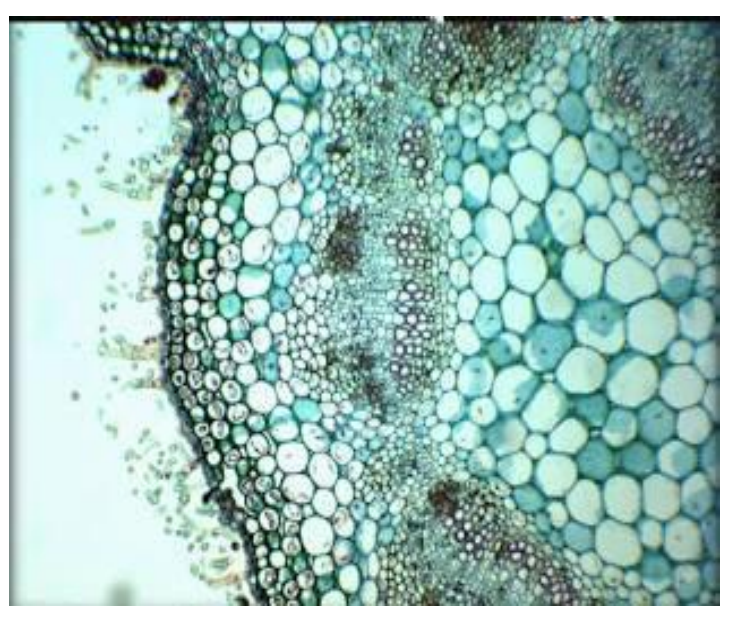

Figure 1: T.S. of Rosmarinus officinalis leaf

\section{Lamina region}

It consists of a thin waxy cuticle present on the upper surface of the leaf. Below the cuticle a single layer of rectangular epidermal cells were observed. Abundant covering trichomes were observed and the covering of trichomes were branched uniseriate, multicellular (3-4 celled) with sharp apex. Below the epidermis mesophyll parenchyma were observed which consists of palisade cells that were along cells near the upper epidermis. They were arranged perpendicular to the epidermal cells. These cells contain chlorophyll which help in photosynthesis and spongy mesophyll cells which contains the vascular elements. The spongy mesophyll cells were loosely packed, with few chloroplasts.

\section{Midrib region}

The cuticle and epidermal cells were observed in the midrib region too. But the palisade cells were found to discontinue in the midrib region. Below the epidermal cells 2-3 layers of collenchyma cells were observed. Below to this the loosely arranged parenchyma cells was found. The Arc shaped vascular bundles were present towards the central region which consists of xylem in the central region and phloem beneath to this was observed. Below the vascular bundles regions 5-6 layers of loosely arranged parenchyma was seen. Strip of collenchyma cells of 1-2 layers of the lower epidermis was observed. The stellate covering of trichomes were seen in the lower epidermis.

\section{T.S of Rosmarinus officinalis stem}

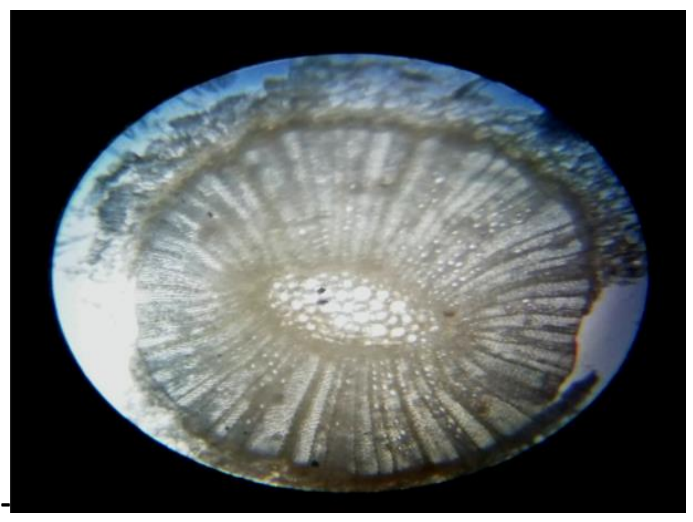

Figure 2: T.S. of Rosmarinus officinalis stem

The T.S of young stem was divided into epidermis, cortex and pith whereas in mature stem the epidermis was replaced by the cork region (Fig.2)

\section{Epidermis}

It was outermost layer of young stem and was formed of single layer of cells. The outer surface of the epidermis was covered by a thin layer of cuticle in younger stem and absent in older stem. Abundant numbers of a covering trichome were observed, the covering trichomes were uniseriate, multicellular, branched. The cork cells were observed in the older stem which were found to be polygonal in shape with brown colour. Trichomes were found to be absent in the older stems. 


\section{Cortex}

Cortex was made up of loosely arranged parenchyma cells with patches of sclrenchyma cells, pericyclic fibres and vascular bundles. The pericyclic fibres were lignified and were found to be 2-3 layers. Vascular bundles present beneath the pericycle. Phloem was observed towards the outer region and xylem region was found beneath the phloem. The xylem vessels and fibres were seen. In the younger stems the vascular bundles region was observed to be narrow, whereas in the older stem the xylem fibres had taken the major portion in the stem. Xylem vessels were found to be narrow and less in number. A layer of endodermis was observed towards the central region below the vascular bundles.

\section{Pith}

The pith was large in the young stem and had taken up the major portion in the section. It was made of thin walled, big polygonal cells with intercellular spaces. In case of older stem the pith was found to be small and the major portion of stem occupied by the xylem fibres.

\section{Powder formation}

Firstly, fresh leaves of Rosmarinus officinalis were cleaned and then dried in the oven. It was then powdered separately with the help of grinder to a coarse powder.

\section{Powder microscopy}

Powder microscopy of leaf revealed the presence of trichome and fibres. Trichome were found long slender with pointed apex. They are uniseriate, covering trichome. It Trichome are branched (multicellular 2-3 celled) (Fig. 3 A-D). Fibre present in leaf powder was long and less in number.

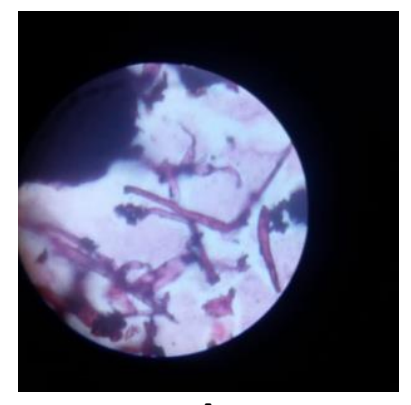

A

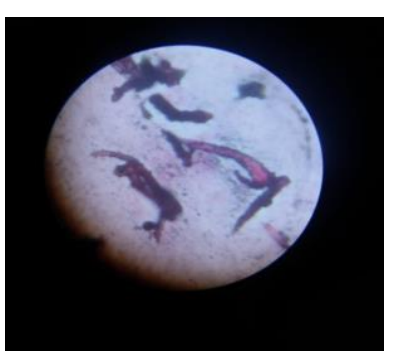

C

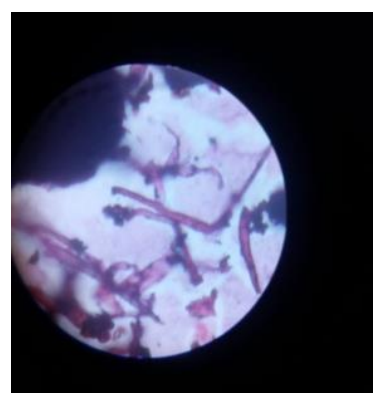

B

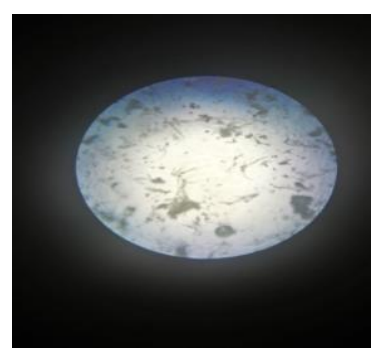

D
Figure 3: A-B- Multicellular and glandular trichomes C-DUnicellular trichomes

Table No 2: HPTLC analysis of methanolic extract of Rosmarinus officinalis

\begin{tabular}{|c|c|c|c|}
\hline \multirow{3}{*}{ No of peaks } & \multicolumn{3}{|c|}{ Inferences (Rf values at different wavelengths) } \\
\hline & UV (566 nm) & UV (366 nm) & UV $(255 \mathrm{~nm})$ \\
\hline & Rf & Rf & Rf \\
\hline 1 & -0.03 & 0.15 & 0.16 \\
\hline 2 & 0.14 & 0.23 & 0.40 \\
\hline 3 & 0.20 & 0.40 & 0.60 \\
\hline 4 & 0.27 & 0.58 & 0.69 \\
\hline 5 & 0.35 & 0.68 & 0.82 \\
\hline 6 & 0.43 & 0.80 & 0.95 \\
\hline 7 & 0.48 & 0.93 & \\
\hline 8 & 0.58 & & \\
\hline 9 & 0.66 & & \\
\hline 10 & 0.91 & & \\
\hline
\end{tabular}

\section{HPTLC Analysis}

Extract of Rosmarinus officinalis leaves shows different Rf values on TLC plate. Only first two lines shows the Rf value of Rosmarinus officinalis 


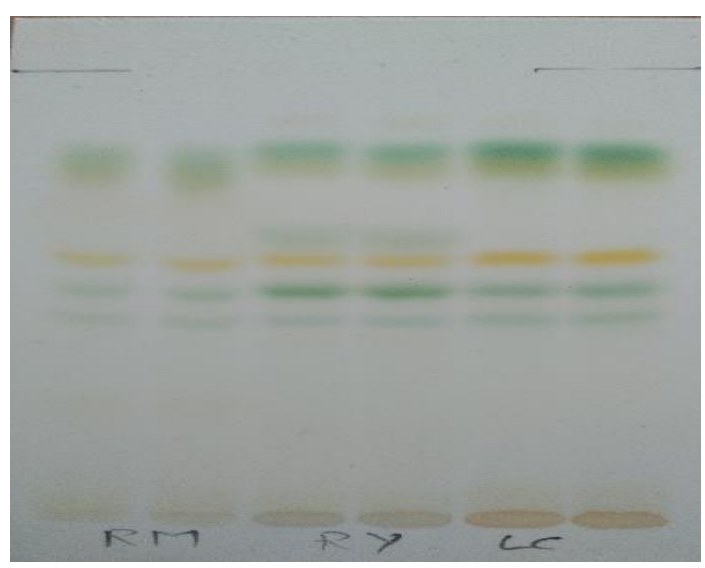

Figure 4: Coloured spots on TLC plate

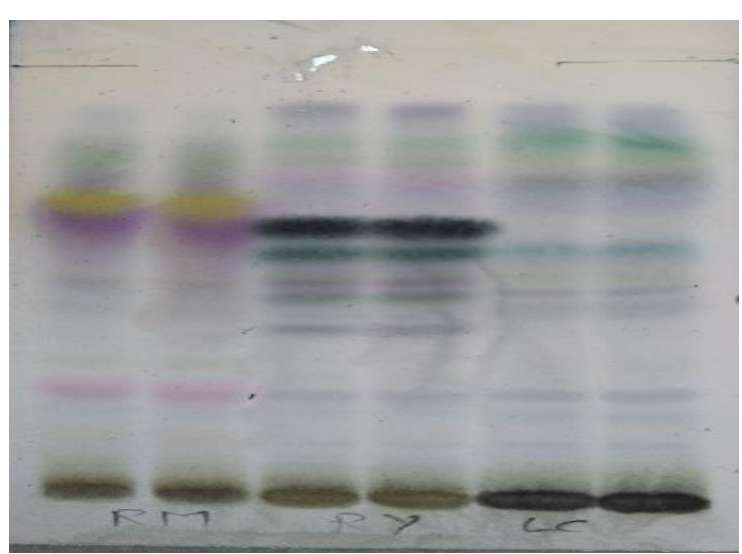

Figure 5: TLC plate after oven drying
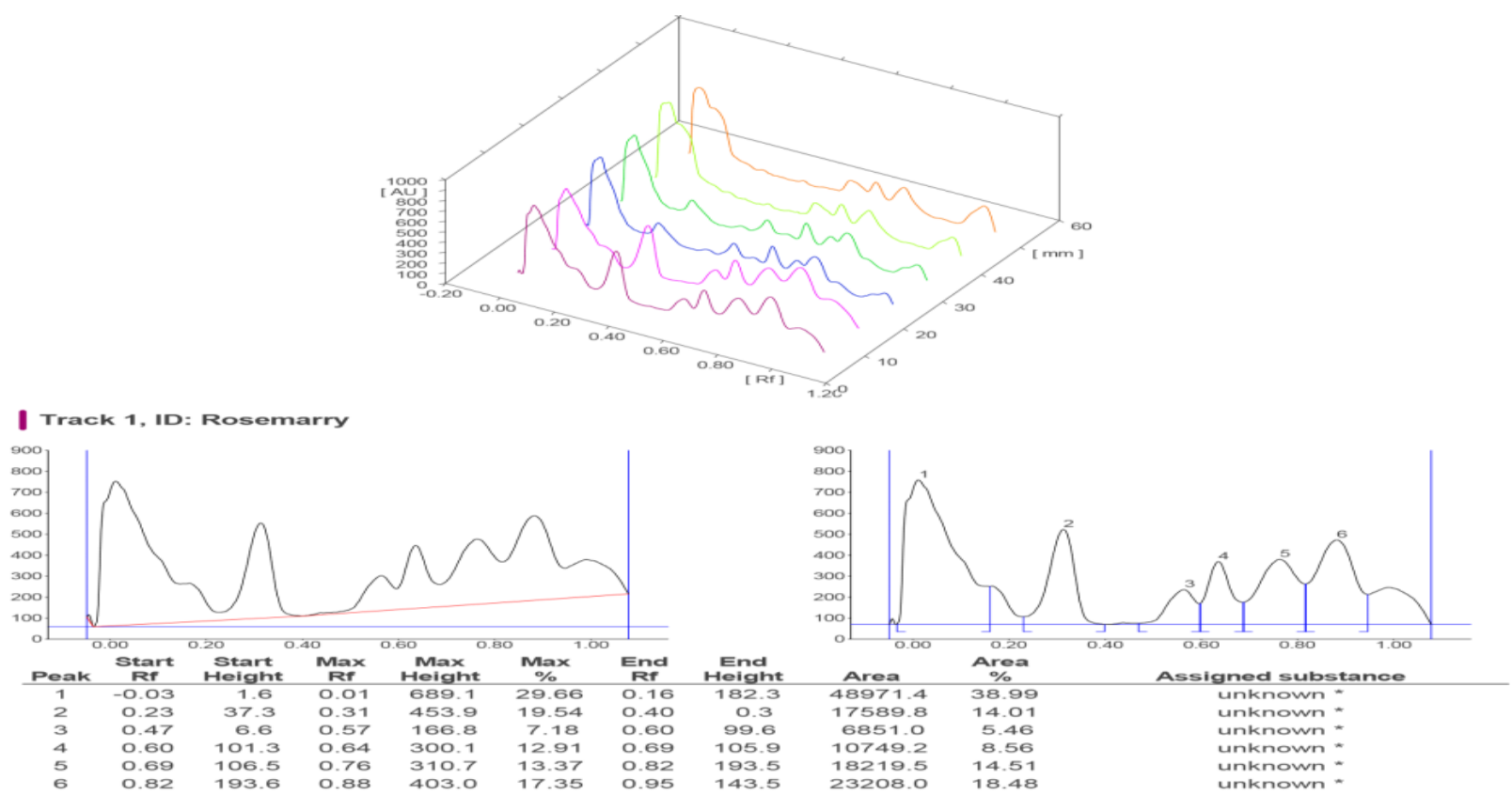

Chromatograph displayed at wavelength $255 \mathrm{~nm}$
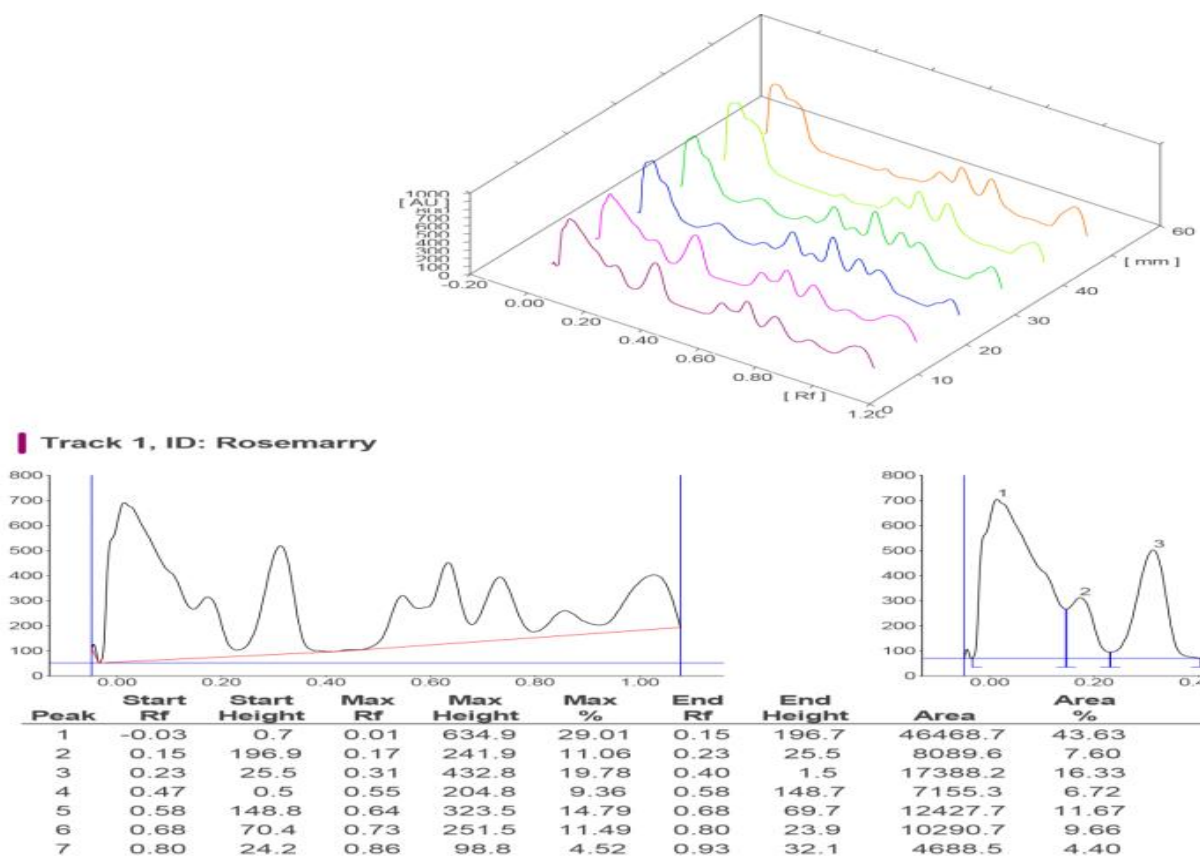

Chromatograph displayed at wavelength $366 \mathrm{~nm}$ 


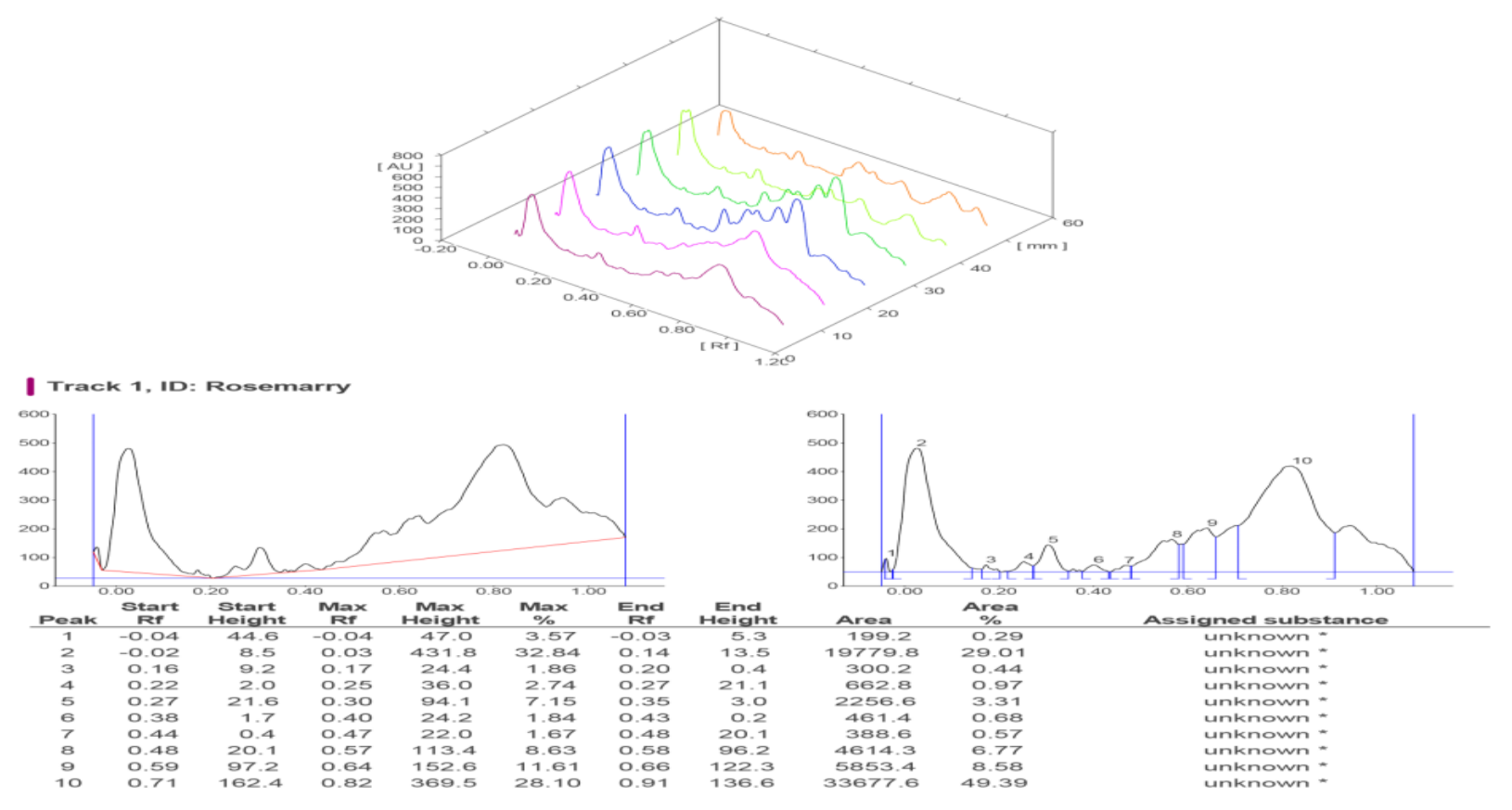

Chromatograph displayed at wavelength $255 \mathrm{~nm}$

\section{CONCLUSION}

The main aim of the present study was to develop and validate a chromatographic method for analysis of various constituents present in the Rosmarinus officinalis using HPTLC technique. The chromatograph with $\mathrm{Rf}$ value of different peaks at different wavelength of $566 \mathrm{~nm}, 366 \mathrm{~nm}$ and $255 \mathrm{~nm}$ are shown in Table 2. It was observed at wavelength $255 \mathrm{~nm}, 6$ peaks whereas at $366 \mathrm{~nm}$ and $566 \mathrm{~nm} 7$ and 10 peaks respectively were observed. Further at wavelengths $255 \mathrm{~nm}$ and $566 \mathrm{~nm}$, three unknown organic constituents showed maximum presence whereas two showed minimum and three showed intermediate concentration. At $366 \mathrm{~nm}$ only two organic constituents showed maximum concentration. This can be concluded that phyto-constituents present in various parts (stem, roots and leaves) of Rosmarinus officinalis also build therapeutical potential of Rosmarinus officinalis in modern medicines and focused on the pharmacological activities and toxicology of Rosmarinus officinalis.

Acknowledgement: We would like to acknowledge Shoolini Institute of life sciences and Business Management (SILB), The Mall, Solan and Shoolini University, Solan (HP), for providing Lab facility and technical assistance for the current research work.

\section{REFERENCES}

1. Bhishagratna and Kaviraj K, editor-translator. Samhita $S, 4$ (2) Chowkhamba Sanskrit Series Office: Varanasi, India, 1991.

2. Guzman, C.C.de, Rosmarinus officinalis L. In: Plant Resources of South-East Asia No. 13: Spices [edited by Guzman, CC de\Siemonsma, J], Leiden, The Netherlands: Backhuys Publisher: 1999; 194-197.

3. Missouri Botanical Garden Plant Finder, Missouri Botanical Garden Plant Finder. St. Louis, MO, USA: Missouri Botanical oil from Rosmarinus officinalis L. in Algeria, Journal of Essential Oil Research, 2014; 10(6): 18-24.

4. Floridata, Floridatabase website. Tallahassee, Florida, USA: 2014

5. Gachkar L, yadegari D, Shakiba M, Food Chemistry, 2007; 102 (3): 898-904.

6. Boutekedjiret, C, Bentahar, F, Belabbes, R and Bessiere, JM, The Essential Oil from Rosmarinus officinalis L. in Algeria 1998; 10(6): 41-46.

7. Celiktas OY, Kocabas EEH, Bedir E, Sukan FV, Ozek T and Baser KHC, "Antimicrobial Activities of Methanol Extracts and Essential Oils of Rosmarinus officinalis, Depending on Location and Seasonal Variations," Food Chemistry, 2006; 100(2): 553-559.

8. Gezici S, Sekeroglu N, Kijjoa A, In vitro Anticancer Activity and Antioxidant Properties of Essential Oils from Populus alba L. and Rosmarinus officinalis L. from South Eastern Anatolia of Turkey, Indian Journal of Pharmaceutical Education and Research, 2017; 51 (3): 30-35.

9. Moore J, Yousef $M$ and Tsiani E, Anticancer effects of Rosemary extract and extract polyphenoils, Nutrients., 2016; 8(11): 731-736.

10. 10.Weerakkody NS, caffin N, lambert LK, Turner MS, Dykes GA, Synergistic antimicrobial activity of galanga (Alpinia galanga), rosemary (Rosmarinus officinalis) and lemon iron bark extracts, Journal of the science of food and agriculture, 2011; 91: 461-468.

11. Calabrese V, Scapagnini G, Catalano C, Biochemical studies of a natural antioxidant isolated from rosemary and its application in cosmetic dermatology, Int J Tissue React, 2000; 22(1): 5-13.

12. Wellwood CRL, Cole RA, Concentrations to the Selection of Rosemary, Rosmarinus officinalis (L.), Accessions for Optimization of Antioxidant Yield, Journal of Agricultural and Food Chemistry, 2004; 52(20): 6101-7. 
13. Barnes J, Anderson L, Phillipson JD. Herbal Medicines. A guide for health-care professionals, 2nd ed. London, Pharmaceutical Press, 2002.

14. Duke JA, Handbook of medicinal herbs. Boca Raton, FL: CRC Press, 1985, 412-3.Eastern Anatolia of Turkey. Indian journal of pharmaceutical education and research

15. S Osawa, E R Weiss, The carboxyl terminus of bovine rhodopsin is not required for $\mathrm{G}$ protein activation, Mol Pharmacol, 1994; 46(6): 1036-40.
16. Williams TI, Weil H. Definition of Chromatography. Nature 1952;170 (4325):503-503.

17. Marston A. Role of advances in chromatographic techniques in phytochemistry. Phytochemistry 2007; 68 (22-24): 2786-2798.

18. Reich E, Schibli A. High-performance Thin-layer Chromatography for the Analysis of Medicinal Plants. Thieme Medical Publishers, Inc., New York 2007.

Source of Support: The author(s) received no financial support for the research, authorship, and/or publication of this article.

Conflict of Interest: The author(s) declared no potential conflicts of interest with respect to the research, authorship, and/or publication of this article.

For any question relates to this article, please reach us at: editor@globalresearchonline.net New manuscripts for publication can be submitted at: submit@globalresearchonline.net and submit_ijpsrr@rediffmail.com 